\title{
Complement Inhibition by Soluble Complement Receptor Type 1 Fails to Moderate Cerulein-Induced Pancreatitis in the Rat
}

\author{
Martin R. Weiser, Simon A. L. Gibbs, \\ Francis D. Moore Jr., and Herbert B. Hechtman* \\ Department of Surgery, Brigham and Women's Hospital, Boston, MA; \\ and The Harvard Medical School, Boston, $M A$
}

Summary

Conclusion: Cerulein-induced pancreatitis in rats associated with remote liver and lung dysfunction. Soluble complement receptor 1 (SCR1) does not reduce the local or remote injury. Thus complement acitvation does not moderate cerulein-induced pancreatitis or the associated liver and lung injury.

Background: The local and remote injury of pancreatitis resembles other inflammatory events that are mediated by complement. This study examines the effect of complement inhibition with $\mathrm{sCR} 1$ in ceruleininduced pancreatitis in rats.

Methods: Thirteen Sprague-Dawley rats received five hourly subcutaneous doses of cerulein (100 $\mu \mathrm{g}$ initially, then $50 \mu \mathrm{g} / \mathrm{kg}$ ). Six of these animals received hourly iv sCR $1(15 \mathrm{mg} / \mathrm{kg}$, a proven complementinhibiting dose in rats) and the other seven received iv saline. In parallel, 12 additional rats received hourly sc and iv saline.

Results: Compared to saline controls, rats receiving cerulein showed increased pancreatic wet-to-dry ratio (3.25:8.52), hematocrit ( 40 to $47 \%)$, ascites volume $(2.1$ to $6.1 \mathrm{~mL})$, serum amylase $(1680$ to $10,700 \mathrm{U} / \mathrm{L})$, and ascites amylase $(32,200$ to $167,000 \mathrm{U} / \mathrm{L})$ (all $p<0.05)$. None of these parameters were modified by treatment with sCR1. Serum SGPT, which increased from 33.4 to $46.6 \mathrm{U} / \mathrm{L}$ in cerulein-infused rats, showed a trend toward reduction to $38.8 \mathrm{U} / \mathrm{L}$ in rats treated with $\mathrm{SCR} 1$. Cerulein-treated rats also had increased lung myeloperoxidase $(0.069$ to $0.097 \mathrm{U} / \mathrm{g})$ and lung permeability, as assessed by alveolar lavage to serum ratio of labeled albumen $(0.041: 0.121)$ (both $p<0.05$ ). Neither were changed by sCR 1 treatment.

Key Words: Acute Pancreatitis; cerulein; complement activation; soluble complement receptor type-1; remote pulmonary injury; neutrophils; inflammation; rodents.

\section{Introduction}

Acute pancreatitis is characterized by acinar cell injury and local edema with release of inflammatory mediators causing multisystem organ failure.

Received April 21, 1995; Revised August 21, 1995; Accepted January 8, 1996.

*Author to whom all correspondence and reprint requests should be addressed: Brigham and Women's Hospital, 75 Francis Street, Boston, MA 02115.
Systemic manifestations include respiratory, renal, and hepatic failure. Pulmonary complications are relatively common (1) with hypoxia in $50 \%$ of patients and, in some instances, the adult respiratory distress syndrome (ARDS). The pathophysiology of acute pancreatitis is unknown, but ethanol ingestion or cholelithiasis is associated in $80 \%$ of cases (2).

Complement activation has been suspected to play a pathogenic role in experimental and clinical 
acute pancreatitis (3-9). Local complement deposition is found with taurocholic acid-induced pancreatitis in the rat (9), and a fall in serum lytic activity (CH50) and C3 levels are found in human pancreatitis (4-8). Some authors suggest that complement activation is responsible for initiating acinar cell damage (9) and that it can cause ARDS in the setting of pancreatitis or other local injuries $(10-14)$. Other investigators believe that, as a consequence of pancreatitis, trypsin is released. This, then, is the primary agent of injury, and it also cleaves soluble complement components, so that complement, per $s e$, is not involved in the pathogenesis of pancreatitis $(15-17)$.

Many models of pancreatitis have been developed including bile duct ligation, intraductal injections of bile acids and proteases, reflux of bile acid into the biliopancreatic duct, choline-deficient diet, and systemic infusion of cerulein, a cholecystokinin analog (18-21). Hyperstimulation with supranormal doses of cholecystokinin is believed to cause organelle dysfunction and enzyme activation (22). This results in edema, focal glandular necrosis, and an acute infiltrate morphologically similar to the reversible edematous pancreatitis seen in man.

Guice et al. have shown that cerulein-induced pancreatitis produces an ARDS-like lung injury with neutrophil sequestration and increased lung permeability (23). The remote lung injury is ameliorated by the induction of neutropenia, complement depletion using cobra venom, or by scavenging oxygen free radicals. Based on this data, they suggest that the injury involves complement activation with production of chemoattractants, such as $\mathrm{C} 5 \mathrm{a}$ and $\mathrm{C} 3 \mathrm{a}$, in turn, leading to neutrophil activation with production of oxygen free radicals and resulting in local and remote endothelial damage with acute lung failure (24).

This study directly tests the role of complement in both local and remote injuries following cerulein infusion by using soluble complement receptor type 1 (sCR 1). Soluble CR 1 is the truncated extracellular domain of CR 1 and is a potent inhibitor of both the alternate and classical complement pathways by causing dissociation of $\mathrm{C} 3$ and $\mathrm{C} 5$ convertases (25). In the doses employed, it has been successful in reducing the local injuries in rodent hindlimb and intestinal ischemia as well as the remote pulmonary injury $(13,14)$.

\section{Methods}

\section{Animal Preparation}

Adult male, virus antibody free, Sprague-Dawley rats (Charles River Laboratories, Wilmington, MA), 450-550 g, were anesthetized with ip sodium pentobarbital $(65 \mathrm{mg} / \mathrm{kg})$ and tail veins were cannulated. Anesthesia was maintained with iv pentobarbital, and the animals kept supine for the duration of the experiment.

\section{Cerulein-Induced Pancreatitis}

Pancreatitis was produced by five hourly injections of cerulein (Sigma St. Louis, MO). At the start of the experiment, $100 \mu \mathrm{g} / \mathrm{kg}$ of cerulein was given subcutaneously followed by $50 \mu \mathrm{g} / \mathrm{kg}$ each hour. Identical volumes of subcutaneous normal saline injections were used as controls.

\section{sCR1 Treatment}

Animals were treated with hourly iv doses of sCR 1 (T Cell Sciences, Cambridge, MA), $15 \mathrm{mg} / \mathrm{kg}$. This dose previously has been shown to completely inhibit the classical and alternative complement pathways (13). Concurrent use of the same batch of this agent in ischemia/reperfusion experiments produced a pronounced therapeutic benefit. Saline vehicle was administered as a control. Soluble CR1 was administered simultaneous to the cerulein injections.

\section{Pancreatic and Liver Injury}

At the end of the fifth hour, the animals were euthanased, a laparotomy was performed and ascites fluid was removed. The ascites volume was measured and assayed for amylase by a quantitative kinetic method involving the hydrolysis of 4,6-ethylidene $\left[\mathrm{G}_{7}\right]-$ p-nitrophenyl $\left[\mathrm{G}_{1}\right]-\alpha, \mathrm{D}$-maltoeptaside to $\mathrm{p}$-nitrophenol, which absorbs light at $405 \mathrm{~nm}$ (Sigma). The pancreas was immediately excised, blotted, weighed, and placed in a drying oven at $90^{\circ} \mathrm{C}$ for $3 \mathrm{~d}$. The wet-to-dry weight ratio was calculated. The hematocrit was measured, as was the change in serum amylase and end serum SGPT assayed by a quantitative kinetic methods measuring the oxidation of reduced nicotinamide adenine dinucleotide spectrophotometrically at $340 \mathrm{~nm}$ (Sigma).

\section{Lung Permeability}

Prior to the cerulein injections, $0.5 \mathrm{~mL}$ of fluorescein isothiocyanate (FITC) conjugated albumin 
Table 1

Local Pancreatic Injury Following Cerulein Infusion

\begin{tabular}{lcccc}
\hline Group ( $n$ ) & $\begin{array}{c}\text { Pancreatic Edema } \\
\text { (Wet/dry ratio) }\end{array}$ & Serum Amylase, U/L & Ascitic Amylase, U/L & Ascitic Volume, mL \\
\hline Sham (14) & $3.25 \pm 0.09^{a, b}$ & $1680 \pm 55.5^{a, b}$ & $2160 \pm 764^{a, b}$ & $2.1 \pm 0.2^{a, b}$ \\
Cerulein (7) & $8.52 \pm 0.39$ & $10,700 \pm 777$ & $167,000 \pm 14,000$ & $6.1 \pm 0.5$ \\
Cerulein and SCR1 (6) & $8.85 \pm 0.29$ & $10,400 \pm 628$ & $166,000 \pm 10.300$ & $4.8 \pm 0.9$ \\
\hline
\end{tabular}

Data expressed as mean $\pm \mathrm{SE}$.

${ }_{b}^{a}<0.05$ comparing sham to cerulein.

$b_{p}<0.05$ comparing sham to cerulein and sCR1.

(Sigma) were given intravenously for lung permeability studies. At harvest, a thoracotomy was performed and a 5-mL sample of blood from the right ventricle removed, and the trachea, lungs, and heart excised en bloc. The left lung was lavaged with $3.3 \mathrm{~mL}$ of saline, three times, for a total of $10 \mathrm{~mL}$. The fluorescence of the lavage fluid and serum was measured and converted to concentration of FITC-albumen using previously developed standard curves for bronchoalveolar lavage (BAL) fluid and serum. Lung permeability index (PI) was calculated from the ratio of the concentration of FITC-albumen in BAL fluid to the concentration of FITC-albumen in serum.

\section{Myeloperoxidase Assay (MPO)}

Pulmonary neutrophil sequestration was quantitated by an assay of MPO. MPO is a heme-containing enzyme within the azurophil granules of neutrophils that constitutes $5 \%$ of the cellular weight. MPO has previously been shown to correlate with neutrophil numbers and is a simple quantitative method to detect neutrophil sequestration $(13,14)$.

The right lung was weighed, and $1 \mathrm{~g}$ of tissue was homogenized with $10 \mathrm{~mL}$ of $0.01 M \mathrm{KH}_{2} \mathrm{PO}_{4}$ and $9 \mathrm{~m} M$ EDTA at $\mathrm{pH} 7.4$. The homogenate was centrifuged at $10,000 \mathrm{~g}$ at $4^{\circ} \mathrm{C}$ for $20 \mathrm{~min}$. The pellet was resuspended in $10 \mathrm{~mL}$ of $0.05 \mathrm{M} \mathrm{K \textrm {KH } _ { 2 }} \mathrm{PO}_{4}$ with $0.5 \%$ hexadecyltriethylammonium bromide at $\mathrm{pH} 6.0$. This was frozen at $-20^{\circ} \mathrm{C}$ overnight and then sonicated for $4 \mathrm{~min}$ and centrifuged at $10,000 \mathrm{~g}$ for $20 \mathrm{~min}$. The final supernatant was collected for MPO.

The assay was performed at $\mathrm{pH} 5.4$ at $37^{\circ} \mathrm{C}$. The mixture contained $0.4 M \mathrm{KH}_{2} \mathrm{PO}_{4}(0.2 \mathrm{~mL}), 16 \mathrm{mM}$ $3,3^{\prime}, 5,5^{\prime}$-tetramethylbenzidine in $N, N$-dimethylformamide $(0.1 \mathrm{~mL}), 150 \mathrm{mMKH} \mathrm{KO}_{4}(0.5 \mathrm{~mL})$, and $0.5 \mathrm{~mL}$ of the sample. The reaction was started by the addition of $3 \mathrm{mM} \mathrm{H} \mathrm{H}_{2} \mathrm{O}_{2}(0.1 \mathrm{~mL})$ and stopped after
$4 \mathrm{~min}$ with $0.002 \%$ bovine catalase $(0.4 \mathrm{~mL})$. Absorbance was measured spectrophotometrically at $655 \mathrm{~nm}$ (Spectronic 601, Milton Roy, Rochester, NY) and compared with a standard curve generated from human MPO (Sigma) to determine the units of $\mathrm{MPO} / \mathrm{gm}$ of tissue (wet weight).

\section{Statistical Analysis}

Results are presented as the mean \pm SEM in the text and tables. All data was subjected to analysis of variance (ANOVA) and, when a significant difference was found, comparisons were performed using the nonpaired Students $t$-test with the Bonferonni correction.

Animals used in this study were maintained in accordance with the guidelines of the Committee on Animals of the Harvard Medical School and those prepared by the Committee on the Care and Use of Laboratory Animals of the Institute of Laboratory Animal Resources, National Research Council (DHHS publication no. (NIH) 85-23, Revised 1985).

\section{Results}

Compared to saline, cerulein administration produced pancreatitis (Table 1). This was documented by an $(p<0.05)$ increase in wet-to-dry weight ratio of the pancreas $(8.52+0.39$ vs $3.25 \pm 0.09)$, a rise in serum amylase $(10,700 \pm 777$ vs $1680 \pm 55.5 \mathrm{U} / \mathrm{L})$ and in ascites fluid amylase $(167,000 \pm 14,000 \mathrm{vs}$ $2,160 \pm 182 \mathrm{U} / \mathrm{L}$ ), and an increased ascites volume $(6.1 \pm 0.5$ vs $2.1 \pm 0.2 \mathrm{~mL})$. Cerulein also produced remote injury (Table 2$)$ as measured by an $(p<0.05)$ increase in lung permeability $(0.121 \pm 0.034$ vs $0.041 \pm 0.011)$, in serum SGPT $(46.6 \pm 3.1 \mathrm{U} / \mathrm{L}$ vs $33.4 \mathrm{U} / \mathrm{L})$, and in hematocrit $(47 \pm 0.8$ vs $40 \pm 0.6 \%)$. The lung injury was further associated with increased 
Table 2

Systemic Changes Following Cerulein Infusion

\begin{tabular}{lcccc}
\hline Group (n) & Hematocrit, \% & Serum SGPT, U/L & Lung permeability index & Lung MPO, U/g tissue \\
\hline Sham (14) & $40 \pm 0.9^{a, b}$ & $33.4 \pm 2.1^{a}$ & $0.041 \pm 0.011^{a, b}$ & $0.069 \pm 0.005^{a}$ \\
Cerulein (7) & $47 \pm 0.8$ & $46.6 \pm 3.1$ & $0.121 \pm 0.034$ & $0.097 \pm 0.008$ \\
Cerulein and SCR1 (6) & $45 \pm 0.6$ & $38.8 \pm 4.0$ & $0.150 \pm 0.025$ & $0.086 \pm 0.007$ \\
\hline
\end{tabular}

Data expressed as mean $\pm \mathrm{SE}$.

$a_{p}<0.05$ comparing sham to cerulein.

$b_{p}<0.05$ comparing sham to cerulein and sCR1.

lung myeloperoxidase $(0.097 \pm 0.008$ vs $0.069 \pm$ $0.005 \mathrm{U} / \mathrm{g}, p<0.05$ ).

Complement inhibition by $\mathrm{sCR} 1$ did not significantly reduce the pancreatic wet-to-dry ratio $(8.85 \pm$ $0.29)$, rise in serum amylase $(10,400 \pm 628 \mathrm{U} / \mathrm{L})$, or rise in ascitic fluid amylase $(166,000 \pm 10,300 \mathrm{U} / \mathrm{L})$. There was a slight decrease in ascitic volume $(4.8 \pm$ $0.9 \mathrm{~mL})$ and a decrease in the hematocrit $(45 \pm 1.4 \%)$, neither of which achieved statistical significance. There was a reduction in remote liver injury with SGPT $38.8 \pm 4.0$ vs $46.6 \pm 3.1 \mathrm{U} / \mathrm{L}$ in untreated animals, but this also did not reach statistical significance. Remote lung injury was not changed with lung permeability $0.150 \pm 0.025$, and lung myeloperoxidase at $0.086 \pm 0.007 \mathrm{U} / \mathrm{g}$.

\section{Discussion}

The spectrum of disease in acute pancreatitis is broad, ranging from mild edematous pancreatitis, which is readily reversible and characterized by pancreatic edema, leukocyte infiltration, and hyperamylasemia to the extreme of severe necrotizing hemorrhagic pancreatitis characterized by acinar cell destruction, fat necrosis, and phlegmon formation with abscess $(26,27)$. Systemic sequelae may include respiratory and hepatic failure (28).

Since the etiology is unclear and the anatomy of the gland varies from species to species, the many models of pancreatitis have limited applicability to man. The question of whether the cholecystokinin analog (cerulein) mimics human disease is unclear. Arguments for its applicability are that increased levels of circulating cholecystokinin are noted in rats with bile-duct obstruction (29), an event leading to pancreatitis in humans secondary to gallstones; however, hyperstimulation of the pancreas by cholecystokinin has not been proven in human pancreatitis, and attempts to block gastric acid secretion or delivery to the proximal small bowel (to suppress cholecystokinin secretion) or treatment with a cholecystokinin antagonist have not been successful in ameliorating the disease $(30-32)$.

Complement activation is suspected to participate in some forms of acute pancreatitis (3-8), with complement deposition around acinar cells following intraductal instillation of tauracholate (9). The interpretive problem is that complement activation may cause pancreatitis (9) or be the result of pancreatitis $(15,16)$. In either case, complement activation might lead to systemic consequences such as ARDS (10-14). The goal of this study was to selectively inhibit complement and thereby test whether this would modify one or more components of this disease. Soluble CR1, a potent inhibitor of both the classical pathway and the alternative pathway (33), was used in doses previously established to completely inhibit complement $(13,14)$.

The mechanism of cerulein-induced pancreatitis is similar to diet-induced and duct obstructioninduced pancreatitis and involves colocalization of zymogen vacuoles and hydrolases causing intra-acinar cell enzyme activation and release into the parenchyma $(22,34)$. This could lead to cleavage of complement proteins in the interstitium. Possible results of such complement activation might include direct acinar and endothelial cell damage with further enzyme release and vascular thrombosis. Indeed, reduced microcirculatory perfusion has been described by intravital microscopy in experimental pancreatitis (35). In addition, complement cleavage products such as $\mathrm{C} 5 \mathrm{a}$ or $\mathrm{C} 3 \mathrm{a}$ might attract and stimulate neutrophils to release oxygen free radicals or elastase in the pancreas. None of these mechanisms nor other complement-dependent mechanisms appeared operative following cerulein infusion since sCR 1 had 
no effect on the local pancreatic injury. Other studies that have employed cobra venom factor to deplete complement have shown no affect on the local pancreatic disease (24).

Cerulein-induced pancreatitis produced remote injury described by increased lung permeability, rise in serum SGPT, and hemoconcentration. This was associated with leukosequestration in the lung as measured by MPO. Since previous studies have shown that cerulein is not directly toxic to ex vivo lung preparations (23), the remote injury may be owing to systemic release of inflammatory mediators, following or leading to neutrophil and complement activation. Soluble CR 1 treatment resulted in a trend toward reduction in remote liver dysfunction. Lung injury and neutrophil sequestration were not affected. This indicates that complement played at most a minor role in the mediation of remote injury following cerulein-induced pancreatitis.

The explanations for our disparate finding relative to other investigators are conjectural. The significant reduction in remote lung injury with cobra venom factor-induced complement depletion (24) may relate to the different method employed to inactivate complement. Two days before the experiment, cobra venom factor was administered. This initially activates and thereby depletes complement. Complement-derived anaphylotoxins such as C3a and C5a circulate, activate neutrophils (36) and produce neutropenia (37). Repeated stimulation of neutrophils with chemoactivators such as $\mathrm{C} 5 \mathrm{a}$ will alter neutrophil function such as diapedesis and subsequent chemotaxis to $\mathrm{C} 5 \mathrm{a}$ ( 38 ). Thus, cobra venom factor may have a more important effect for this pancreatitis model by reducing neutrophil number and function as well as the intended effect on complement. Soluble CR1 specifically inhibits the classical and alternative complement pathways by dissociating the $\mathrm{C} 3$ and $\mathrm{C} 5$ convertases (25) and does not modify neutrophil function as no anaphylatoxins are generated. If neutrophils are key inducers of remote injury, cobra venom factor but not sCR1 might therefore be expected to reduce that injury.

In summary, our data indicate that complement is not involved in the pathogenesis of ceruleininduced pancreatitis. Further remote lung and liver injury are minimally affected by complement inactivation.

\section{Acknowledgments}

The authors wish to thank Denise Smith and Cindy Barlow for their assistance and support.

This article was supported in part by The National Institutes of Health, Grants No. GM24891-14, GM35141-06, HL43875-02; The Brigham Surgical Group, and The Trauma Research Foundation.

\section{References}

1 Carey LC. Extra-abdominal manifestations of acute pancreatitis. Surgery 1979; 86: 337-342.

2 Ranson JHC. Etiological and prognostic factors in human acute pancreatitis: a review. Am J Gastroent 1982; 77: 663-683.

3 Horn JK, Ranson JHC, Goldstein IM, Weissler J, Curatola K, Taylor R, Perez D. Evidence of complement catabolism in experimental acute pancreatitis. Am J Pathol 1980; 101: 205-215.

4 Lankisch PG, Koop H, Kaboth U. Serum complement factors in human acute pancreatitis; Hepato-gastroenterol 1981; 28: 261-263.

5 Minta JO, Man D, Movat HZ. Kinetic studies on the fragmentation of the third component of complement (C3) by trypsin. J Immunol 1977; 118: 2192-2198.

6 Perez HD, Horn JK, Ong R, Goldstein IM. Complement (C5)-derived chemotactic activity in serum from patients with pancreatitis. J Lab Clin Med 1983; 101: 123-129.

7 Lasson A, Laurell AB, Ohlsson K. Correlation among complement activation, protease inhibitors, and clinical course in acute pancreatitis in man. Scand J Gastroent 1985; 20: 335-345.

8 Foulis AK, Murray WR, Galloway D, McCartney AC, Lang E, Veitch J, Whaley K. Endotoxaemia and complement activation in acute pancreatitis in man. Gut 1982;23:656-661.

9 Seelig R, Tschahargane EC, Seelig HP. The serum complement system-a mediator of acute pancreatitis. Virchows Arch Path A Anat and Histol 1975; 365: 193-199.

10 Tahamont MV, Barie PS, Blumenstock FA, Hussain MH, Malik AB. Increased lung vascular permeability after pancreatitis and trypsin infusion. Am J Pathol 1982; 109: 15-26.

11 Hohn DC, Meyers AJ, Gherini ST, Beckmann A, Markison RE, Churg AM. Production of acute pulmonary injury by leukocytes and activated complement. Surgery 1980; 88; 48-58.

12 Hammerschmidt DE, Weaver LJ, Hudson LD, Craddock PR, Jacob HS. Association of complement activation and elevation and elevated plasma-C5a with adult respiratory distress syndrome, pathophysiological relevance and possible prognostic value. Lancet 1980; 8175: 947--949.

13 Hill J, Lindsay TF, Ortiz F, Yeh CG, Hechtman HB, Moore FD Jr. Soluble complement receptor type 1 ameliorates the local and remote organ injury after intestinal ischemiareperfusion in the rat. $J$ Immunol 1992; 149: 1723-1728.

14 Lindsay TF, Hill J, Ortiz F, Rudolph A, Valeri CR, Hechtman HB, Moore FD Jr. Blockade of complement activation prevents local and pulmonary albumen leak after 
lower torso ischemia-reperfusion. Ann Surg 1992; 216: 677-683.

15 Whicher JT, Barnes MP, Brown A, Cooper MJ, Read R, Walters $\mathrm{G}$, Williamson RCN. Complement activation and complement control proteins in acute pancreatitis. Gut 1982; 23: 944-950.

16 Kelly RH, Rao KN, Harvey VS, Lombardi B. Acute hemorrhagic pancreatic necrosis in mice: lack of a pathogenetic role for complement. Acta Hepato-Gastroenterol 1979; 26: 302309.

17 Kelly RH, Rao KN, Harvey S, Lombardi B. Acute hemorrhagic pancreatic necrosis in mice: alterations of serum complement. Digestion 1981,22: 1-7.

18 Steer ML. Workshop on Experimental pancreatitis. Dig Dis Sci 1985; 30: 575-581.

19 Orda R, Hadas N, Orda S, Wiznitzer T. Experimental acute pancreatitis. Arch Surg 1980; 115: 327-329.

20 Aho HJ, Koskensalo SML, Nevalainen TJ. Experimental pancreatitis in the rat. Scand J Gastroent 1980; 16:411-416.

21 Zhou W, Levine BA. Olson MS. Platelet-activating factor: a mediator of pancreatic inflammation during cerulin hyperstimulation. Am J Pathol 1993; 142: 1504-1512.

22 Lampel M, Kern HF. Acute interstitial pancreatitis in the rat induced by excessive doses of a pancreatic secretagogue. Virchows Arch Path A Anat and Histol 1977; 373: 97-117.

23 Guice KS, Oldham KT, Johnson KJ, Kunkel RG, Morganroth ML, Ward PA. Pancreatitis-induced acute lung injury. Ann Surg 1988; 208: 71-77.

24 Guice KS, Oldham KT, Caty MG, Johnson KJ, Ward PA. Neutrophil-dependent, oxygen-radical mediated lung injury associated with acute pancreatitis. Ann Surg 1989; 210: $740-747$.

25 Fearon DT. Regulation of the amplification C3 convertase of human complement by an inhibitory protein isolated from human erythrocyte membrane. Proc Natl Acad Sci USA 1979; 76: 5867-5871.

26 Kloppel G. Pathology of acute pancreatitis, in Acute Pancreatitis: Diagnosis and Therapy, Bradley EL, ed., Raven, New York, 1994; pp. 35-46

27 Steer ML. Pathophysiology and pathogenesis of acute pancreatitis, in Acute Pancreatitis: Diagnosis and Therapy, Bradley EL, ed., Raven, New York, 1994; pp. 3-11.
28 Ranson JHC. Stratification of severity for acute pancreatitis, in Acute Pancreatitis: Diagnosis and Therapy, Bradley EL, ed., Raven, New York, 1994; pp. 13-20.

29 Toriumi Y, Samuel I, Wilcockson DP, Turkelson CM, Solomon TE, Joehl RJ. Increased circulating cholecystokinin in obstruction-induced acute pancreatitis I. Bile duct obstruction with and without pancreatic duct obstruction. $J$ Surg Res 1993; 54: 132-135.

30 Freston JW, Cimetidine I. Development, pharmacology, and efficacy. Ann Intern Med 1982; 97: 573-580.

31 Saluja AK, Saluja M, Printz H, Zavertnik A, Sengupta A, Steer ML. Experimental pancreatitis is mediated by lowaffinity cholecystokinin receptors that inhibit digestive enzyme secretion. Proc Natl Acad Sci USA 1989; 86: 89158-8971.

32 Nordback IH, Clemens JA, Cameron JL. The role of cholecystokinin in the pathogenesis of acute pancreatitis in the isolated pancreas preparation. Surgery 1991; 109:301-306.

33 Weisman HF, Bartow T, Leppo MK, Marsh HC Jr, Carson GR, Concino MF, Boyle MP, Roux KH, Weisfeldt ML, Fearon DT. Soluble human complement receptor type $1:$ in vivo inhibitor of complement suppressing post-ischemic myocardial inflammation and necrosis. Science $1990 ; 249$ : 146-15 1

34 Steer ML. How and where does acute pancreatitis begin? Arch Surg 1992; 127: 1350-1353.

35 Klar E, Mall G, Messmer K, Herfarth C, Rattner DW, Warshaw AL. Improvement of impaired pancreatic microcirculation by isovolemic hemodilution protects pancreatic morphology in acute biliary pancreatitis. Surg Gynecol Obstet 1993; 176: 144-150.

36 Zimmerli W, Reber AM, Dahinden CA. The role of formylpeptide receptors, C5a receptors, and cytosolic-free calcium in neutrophil priming. $J$ Infect Dis 1990; 161: 242-249.

37 Kajita T, Huglia TE. C5a-induced neutropenia. A primary humoral mechanism for recruitment of neutrophils. Am J Pathol 1990; 137: 467-77.

38 Goldman G, Welbourn R, Klausner JM, Kobzik L, Valeri CR, Shepro D, Hechtman HB. Intravascular chemoattractants inhibit diapedesis by selective receptor occupancy. Am J Physiol 1991; 260: H465-H472. 